\title{
DETERMINATION OF SUCROSE ADDITIVES AND GEOGRAPHICAL ORIGIN MARKERS IN HONEY USING ISOTOPE RATIO MASS SPECTROMETRY AND ULTRA HIGH PERFORMANCE LIQUID CHROMATOGRAPHY - EVOPARATIVE LIGHT SCATTERING DETECTION
}

\author{
Krišs Dāvids Labsvārds ${ }^{1,2, \#}$, Lauma Buša ${ }^{1}$, Kristīne Meile ${ }^{3}$, and Arturs Vīksna ${ }^{1}$ \\ ${ }^{1}$ Faculty of Chemistry, University of Latvia, 1 Jelgavas Str., Rīga, LV-1004, LATVIA \\ 2 Institute of Food Safety, Animal Health and Environment "BIOR", 3 Lejupes Str., Rīga, LV-1076, LATVIA \\ ${ }^{3}$ Latvian State Institute of Wood Chemistry, 27 Dzērbenes Str., Rīga, LV-1006, LATVIA \\ \# Corresponding author: kriss_davids.labsvards@lu.Iv
}

Communicated by Ina Alsiṇa

\begin{abstract}
Honey can easily be adulterated with various cheaper sweeteners for higher commercial profits. Commonly used adulterants include high fructose maize syrup and refined cane sugar, which origin is $C_{4}$ plants. Isotope ratio mass spectrometry (IRMS) can be used to determine the adulteration of honey with $C_{4}$ plants. A significant $\delta^{13} \mathrm{C}$ value difference between honey and its protein provide valuable information of honey authenticity. The IRMS analysis of honey and its proteins and ultra high performance liquid chromatography - evoparative light scattering detection analysis for adulterated honey were performed to assess honey authenticity and origin. Principal component analysis of the obtained IRMS data was performed in order to determine discrimination between groups and for visualisation of observations. The results showed that isotope ratio values in combination with principal component analysis could be useful for determination of adulterant and discrimination of honey of different geographical origins. The chromatography results show ascending increase of the deliberately added sucrose, but do not fully recover the expected value.
\end{abstract}

Keywords: honey, IRMS, UHPLC, $C_{4}$ plants, principal component analysis.

\section{INTRODUCTION}

Honey is a unique natural product that is widely used on a daily basis as a sweetener or additive in cooking. Due to its antibacterial properties, it is often used in folk medicine as a remedy. Due to its versatile use, honey is a product in demand on the market. However, naturally obtained honey is expensive, compared to other sweeteners. Counterfeit honey is considered to be honey that contains impurities of other cheaper sweeteners. It is in the interest of consumers to know the authenticity of the product, which is also confirmed by Directive 2014/63/EU of the European Parliament and of the Council. New methods for determining honey quality indicators are being developed. In the case of complicated counterfeits, mass spectrometry of light stable isotopes together with chromatographic methods is quite effective. Analysis of $\delta^{13} \mathrm{C}$ values of honey and its protein reveal an impurity of $7 \%$ in maize or sugar cane syrups. Unfortunately, the elemental analyser-isotope ratio mass spectrometry (EA-IRMS) method is not preffered to detect the addition of sugar beet syrup to honey, although in combination with liquid chromatography (LC-IRMS) it is widely used for assesment of honey quality (Dong et al., 2018). By analysing the $\delta^{18} \mathrm{O}$ values, the regional origin of the honey sample can be estimated, while $\delta^{15} \mathrm{~N}$ is an important indicator of environmental fertiliser use and the local floral environment (Chiochinni et al., 2018; Xie et al., 2020).

The most common intentionally added impurities in the production of honey are glucose, sucrose syrups from sugar 
beet or sugar cane, as well as invert sugar syrups. The addition of invert sugar syrup to honey results in the closest imitation of natural honey, making such counterfeiting more difficult to detect using economic methods and simple laboratory methods (Siddiqui et al., 2017).

To calculate the sugar concentration of $\mathrm{C}_{4}$ plant origin it is necessary to measure the carbon isotope ratio of honey proteins and honey itself. Dialysis is a physical protein purification method that uses a semi-permeable membrane with a specific molecular size permeability to release proteins. Salting-out is an alternative chemical protein purification method. Although it is a chemical method, the proteins usually are not damaged (Bocian et al., 2017; Wu et al., 2017).

The main aim of this study was to improve analysis of honey samples to verify the quality and authenticity of protected destination of origin (PDO) labeled products. The presence of sucrose of $\mathrm{C}_{4}$ plant origin was evaluated using IRMS and total sucrose concentration was determined using ultra high performance liquid chromatogrphy (UHPLVELSD). The obtained $\delta^{13} \mathrm{C}$ for honey proteins was used as an internal standard for carbon of natural origin. Another objective was to study the suitability of IRMS for discrimination of honey of different geographical origin. Fur this purpose, the $\delta^{15} \mathrm{~N}$ and $\delta^{18} \mathrm{O}$ values were used as additional variables.

\section{MATERIALS AND METHODS}

Samples. Twenty-nine honey samples were used in the study. Forteen samples had the origin of Latvia, six of Georgia, three of Russia, region of Tomsk, and one sample had the origin of Ukraine. Five honey samples were deliberately counterfeited with cane sugar. Counterfeits were prepared using $3 \%, 6 \%, 9 \%, 12 \% \%$, and $15 \%$ of sucrose of $\mathrm{C}_{4}$ plant origin. The Latvian honey of natural origin was used for counterfeit preparation.

Proteins were extracted by method of dialysis. Approximately $20 \mathrm{~cm}$ semi-permeable SnakeSkin dialysis membranes were measured and a straight cut was made at a $90^{\circ}$ angle. The cut membrane was placed in deionised water for about 20 minutes to make the membrane more flexible. Crystallised honey samples were placed in a water bath at $40{ }^{\circ} \mathrm{C}$. The water temperature was carefully monitored to prevent protein denaturation. $15 \mathrm{~g}$ of the sample was diluted to a $1: 1$ (v/v honey:water) ratio and the solution was quantitatively transfered to a membrane.

The water from the dialysis was changed for the first time after six hours, and then the water was changed again every 12 hours. In total, the dialysis process was performed for about 42 hours. The purified protein solution was poured into a beaker and placed in a drying oven for about 12 hours at $44.5^{\circ} \mathrm{C}$ until all the water had evaporated.

Isotope ratio mass spectrometry. $\sim 1 \mathrm{mg}$ of honey or honey proteins were used for IRMS analyses. $\delta^{13} \mathrm{C}$ was measured for all honey samples and $\delta^{18} \mathrm{O}$ for ten honey samples. $\delta^{13} \mathrm{C}$ and $\delta^{15} \mathrm{~N}$ was measured for all honey proteins and $\delta^{18} \mathrm{O}$ for ten honey proteins.

Continuous flow IRMS Nu Horizon (mass range 2-100 Da, mass dispersion $30 \mathrm{~cm}$ ) coupled with an elemental analyser EuroEA3024 (combustion reactor temperature set to 1030 ${ }^{\circ} \mathrm{C}$, reduction reactor set to $650{ }^{\circ} \mathrm{C}$ ) was used for carbon and nitrogen isotope analyses, and a high temperature elemental analyser HT-PyrOH (combustion reactor temperature set to $1430{ }^{\circ} \mathrm{C}$ ) was used for oxygen isotope analyses.

The $\delta^{13} \mathrm{C}$ was expressed to V-PDB (Vienna Pee Dee Belemnite) and $\delta^{15} \mathrm{~N}$ to air. The approximate sugar concentration of $\mathrm{C}_{4}$ plant origin \%owas calculated for all honey samples by using the equation

sugar of $\mathrm{C}_{4}$ plant origins $(\%)=\frac{\delta^{13} \mathrm{C}_{\text {protein }}-\delta^{13} \mathrm{C}_{\text {honey }}}{\delta^{13} \mathrm{C}_{\text {protein }}-(9.7 \% 0)} \cdot 100$.

The mean $\delta^{13} \mathrm{C}$ value $-9.7 \%$ was used for $\mathrm{C}_{4}$ plant sugars (Wu et al., 2017).

Ultra high performance liquid chromatography - evaporative light scattering detection chromatography (UHPLC-ELSD) analysis was performed for five honey counterfeits with different deliberatively added sugar weight fraction and the original natural honey. A Waters Acquity UHPLC system with Waters Acquity UHPLC BEH Amide column $(100 \mathrm{~mm} \times 2.1 \mathrm{~mm}, \varnothing 1.7 \mu \mathrm{m})$ combined with Waters ELSD was used for quantitative purposes and a Waters quadrpole mass spectrometer in negative ESI ionisation for qualitative purposes. The flow rate was 0.15 $\mathrm{ml} \cdot \mathrm{min}^{-1}$ isocratic $1: 1(\mathrm{v} / \mathrm{v})$ of mixture A (40\% acetonitrile $+0.1 \% \mathrm{NH}_{3} \cdot \mathrm{H}_{2} \mathrm{O}$ ) and $\mathrm{B}$ (acetonitrile). Detection gain was set for 100 , evaporation temperature was $40^{\circ} \mathrm{C}$, and nitrogen pressure was $2.0 \mathrm{~atm}$.

A standard solution series of D-(+)-glucose and D-(+)-sucrose $0.30-1.55 \mathrm{mg} \cdot \mathrm{ml}^{-1}$ was used for quantitative analysis. $\sim 0.15 \mathrm{~g}$ of raw honey sample was diluted into acetonitrile and water solution $1: 1(\mathrm{v} / \mathrm{v})$ in a $25 \mathrm{ml}$ volumetric flask. The injection volume was $2 \mu \mathrm{l}$. After the analysis, the characteristic UHPLC-ELSD chromatogram of pure honey was obtained (Fig. 1).

\section{RESULTS}

Isotope ratio mass spectrometry results. None of the natural or adulterated honey samples exceeded the critical $7 \%$ mark when honey is considered to be adulterated. For most of the honey samples $\delta^{13} \mathrm{C}_{\text {honey }}<\delta^{13} \mathrm{C}_{\text {proteins }}$, except for three samples where $\delta^{13} \mathrm{C}$ of its proteins was more depleted than $\delta^{13} \mathrm{C}$ of honey $\left(\delta^{13} \mathrm{C}_{\text {honey }}>\delta^{13} \mathrm{C}_{\text {proteins }}\right)$, resulting in a positive outcome of sugar of $\mathrm{C}_{4}$ plant origin concentration that does not exceed by $7 \%$. Using the original measured $\delta^{13} \mathrm{C}$ value $(-12.5 \%$ of of pure adulterant, the results showed that none of adulterated honey samples would exceed $\mathrm{C}_{4}$ concentration of $7 \%$.

$\delta^{13} \mathrm{C}$ values of natural honey were in the range of $-28.7 \%$ to $-24.5 \%$ and $\delta^{15} \mathrm{~N}$ (vs air) of honey proteins was from 


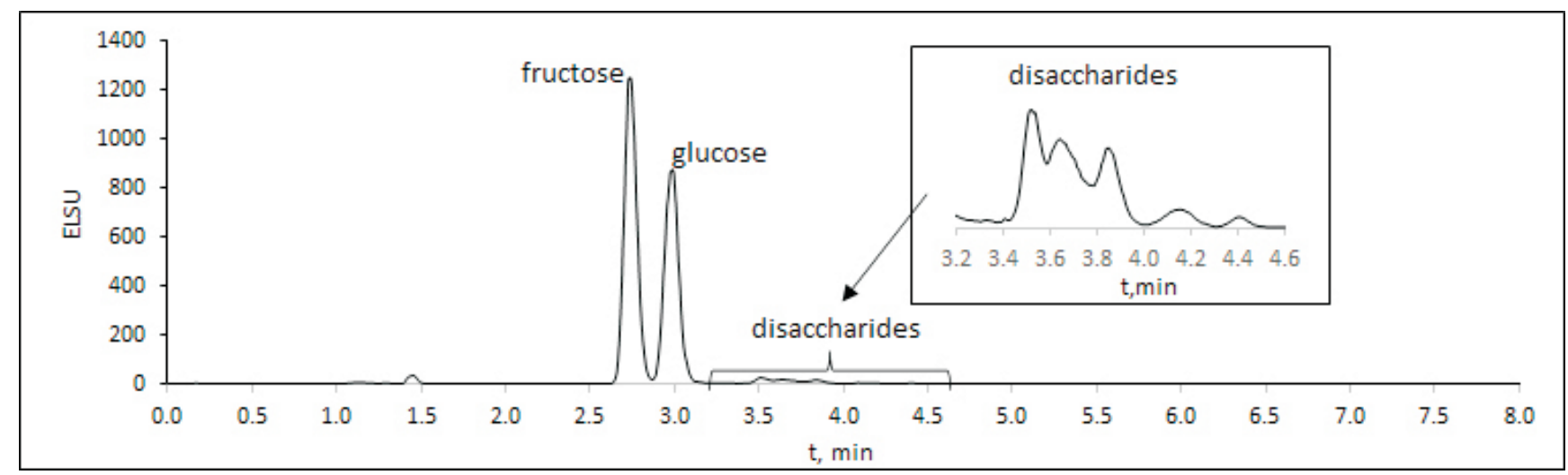

Fig. 1. Ultra high performance liquid chromatography - evaporative light scattering detection chromatogram of pure honey main monosaccharides (fructose and glucose) and disaccharide retention times.

$2.4 \%$ to $7.9 \%$. None of groups of places of origin were significally different from each other by comparing $\delta^{13} \mathrm{C}$ of honey and $\delta^{15} \mathrm{~N}$ of proteins. $\delta^{18} \mathrm{O}$ values of honey of different geographical origin were in the range from $17.8 \%$ to $25.5 \%$ while $\delta^{18} \mathrm{O}$ values of honey proteins were $9.4 \%$ to $23.3 \%$. The results showed that $\delta^{18} \mathrm{O}$ values of honey and proteins for samples of origin of Russia (Tomsk region) were different from honey samples of origin of Latvia, Georgia, or Ukraine by using one-way ANOVA test, $\alpha=$ 0.05 .

The sugar concentration of $\mathrm{C}_{4}$ plant origins, $\delta^{13} \mathrm{C}$ of honey, $\delta^{13} \mathrm{C}$, and $\delta^{15} \mathrm{~N}$ of proteins were used for principal compo- nent analysis of adulterated and samples of origin of Latvia. The results are shown in 3D plot in Figure 2. The adultered samples were located further from centre and the natural sample group. The observed differences in principal component scores might be used for counterfeit determination. The biplot of the first two principal components was constructed for honey samples of different geographical origin and adulterated honey samples. The used variables for the biplot were $\delta^{13} \mathrm{C}$ and $\delta^{18} \mathrm{O}$ of honey and proteins and $\delta^{15} \mathrm{~N}$ of proteins (Fig. 3).

Ultra high performance liquid chromatography - evaporative light scattering detection chromatography results.
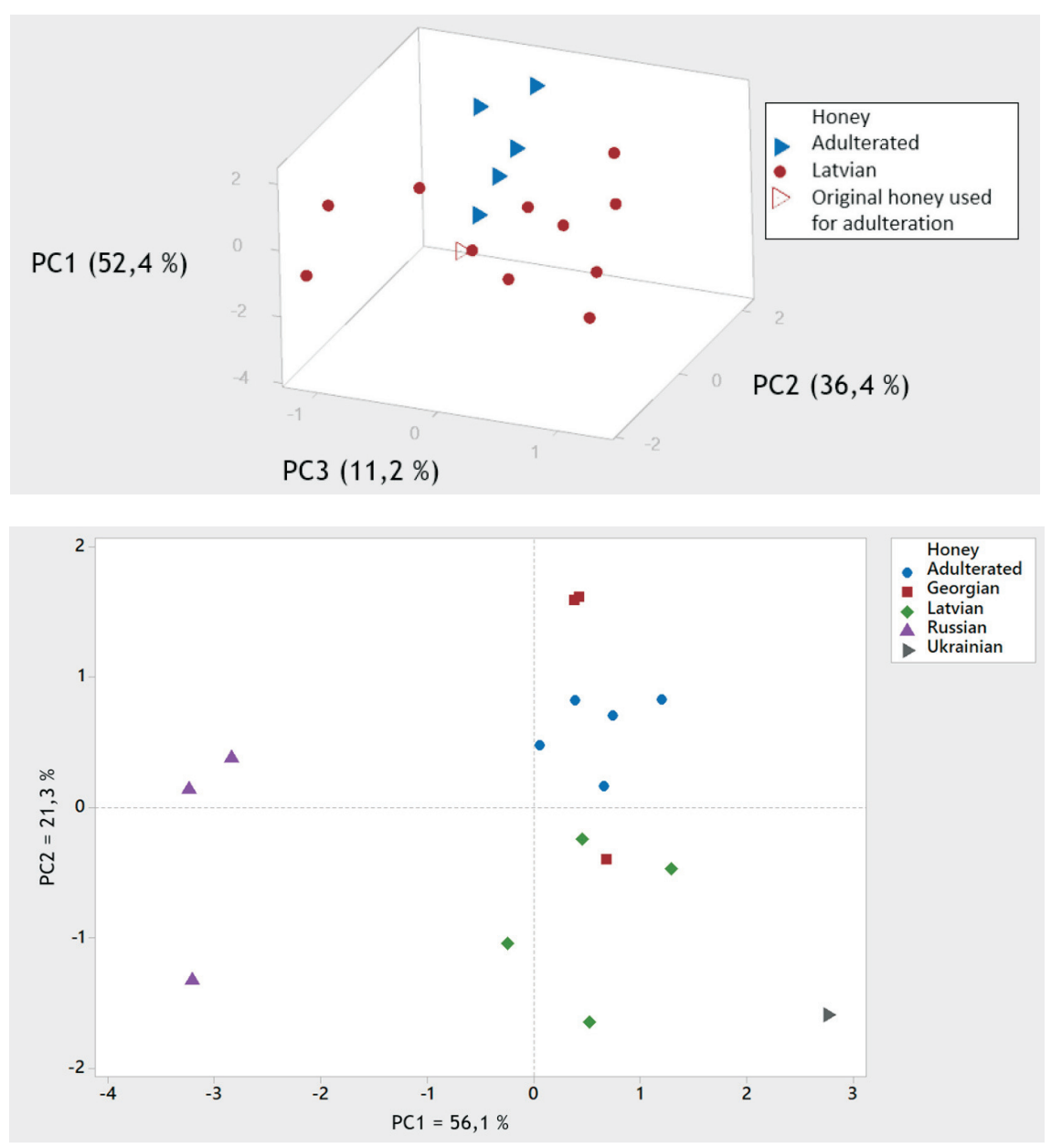

Fig. 2. Comparison of adulterated and natural honey of origins of Latvia by using a 3D PCA scatterplot. As variables, $\mathrm{C}_{4}$ sugar concentration, $\delta^{15} \mathrm{~N}$ of proteins and $\delta^{13} \mathrm{C}$ of honey and proteins were used.
Fig. 3. Comparison of adulterated and natural honey of different geographical origins by using scatterplot of first two principal components. As a variables $\delta^{13} \mathrm{C}$ and $\delta^{18} \mathrm{O}$ of honey and proteins and $\delta^{15} \mathrm{~N}$ of proteins were used. 


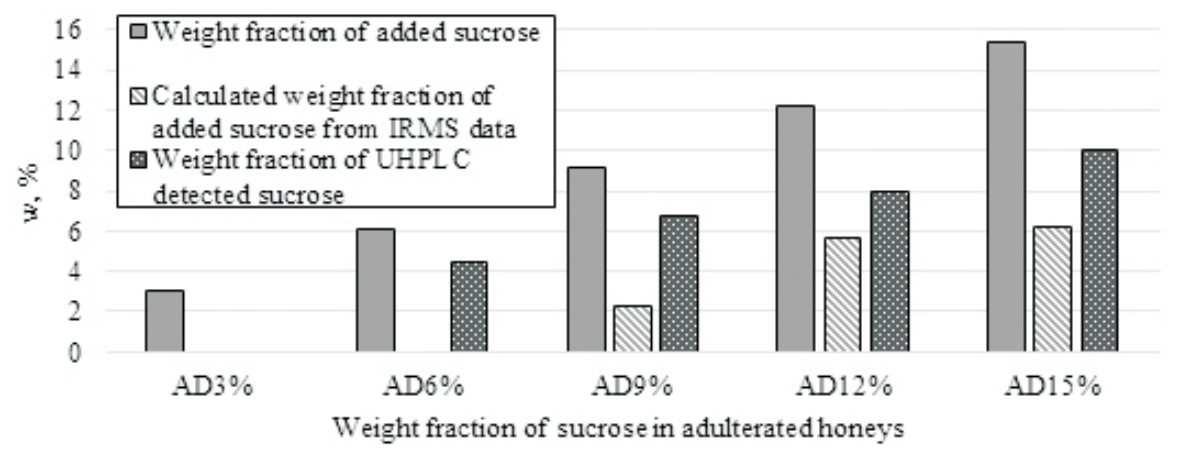

Fig. 4. Deliberately added sucrose concentration in adulterated honey samples compared to total sucrose concentration obtained from ultra high performance liquid chromatography (UHPLC) method and $\mathrm{C}_{4}$ plant origins sugar concentration calculated of isotope ratio mass spectrometry (IRMS) obtained data.
UHPLC-ELSD analysis was performed for the used adulterant and the results show that sucrose was pure and did not contain fructose or glucose more than 3\%. There was a higher sucrose total concentration, obtained by UHPLCELSD, corresponding to honey samples of deliberately added sucrose, but not exceeding the added quantity. No increase was observed of total glucose and fructose concentration corresponding to honey samples of deliberately added sucrose. The estimated glucose/fructose ratio (0.78 \pm 0.02) differed slightly.

The results of analysis of deliberately added sucrose in adulterated honey samples estimated by both used methods (IRMS \& UHPLC-ELSD) are summarised in Figure 4.

\section{DISCUSSION}

Measured $\delta^{13} \mathrm{C}$ values showed that natural honey and its proteins are characterestic to $\mathrm{C}_{3}$ plants from which bees usually gather honey (Wu et al., 2017). The stable carbon isotope ratio method is not capable of detecting the adulteration of honey with sugar syrups from $\mathrm{C}_{3}$ plant origins (beet, wheat, rice, etc.), but it is considered to be a powerful technique for the detection of honey adulterated with sugars of $\mathrm{C}_{4}$ plant origin (maize or cane). Recent studies showed that this type of adulterant is still common (Geanć et al., 2020). The range of $\delta^{13} \mathrm{C}$ values could be explained with different floral origin of honey samples and time of collection, since $\delta^{13} \mathrm{C}$ values slightly depend on the number of sunny days and sunshine duration (Schellenberg et al., 2010). Despite different geographical origin and different climate, the $\delta^{13} \mathrm{C}$ values did not indicate geographical origin of the studied samples. Although $\delta^{13} \mathrm{C}$ values are not generally suited for identification of geographical origins, their application can be found (Vasić et al., 2020; Berriel, 2018).

$\delta^{15} \mathrm{~N}$ is an indicator of soil of the area where bees have collected honey. Since all honey samples were in a positive range, the honey must have been gathered from plants of mainly naturally fertilised topsoil. Synthetic fertilizers have characteristic depleted values, while for plants that obtain nitrogen from the atmospshere $\delta^{15} \mathrm{~N}$ is near $0 \%$. (Bateman et al., 2005; Schellenberg et al., 2010). Also, low $\delta^{15} \mathrm{~N}$ values below $0 \%$ are characteristic to heather (Calluna vulguris) honey of origin of Latvia (Labsvards et al., 2022). The obtained results do not show promising use of $\delta^{15} \mathrm{~N}$ as an adulteration indicator, yet it could be a helpful variable for assesment of botanical origins. Since $\delta^{13} \mathrm{C}$ and $\delta^{15} \mathrm{~N}$ of honey proteins can be determined simultaneously in single analysis run, this gives the option to evualate honey origins and authenticity for routine analysis.

$\delta^{18} \mathrm{O}$ values of honey proteins were clearly depleted compared to the corresponding honey. Comparing isotope ratio results, the $\delta^{18} \mathrm{O}$ shows best results for discrimination of geographical origin with the condition that the range is far enough. Since the distance from ocean to Latvia, Georgia, or Ukraine is not large, compared to the Tomsk region of Russia, it is difficult to discriminate geographical origin with the small sample size used. In another study of honey from France to Romania, there also was not sufficient discrimination of geographical origin (Magdas et al., 2021).

The use of principal component score plots even for the small number of variables gives a simple and fast overview of the obtained data and identifies possible groups to discriminate. The $3 \mathrm{D}$ scatterplot is more useful when data are well centered ir order to find the best perspective. To identify counterfeit in such a manner could be a difficult task if the natural sample data is not strongly centered and counterfeits are not far enough, but certain changes in the principal component scores were observed that could be used for future research. An addition of variables that are used for honey evaluation would be needed. For widely scattered data, biplots of first two principal components are convenient to use. The discrimination of honey of origins of Russia was observed and differences of $\delta^{18} \mathrm{O}$ values confirmed this.

Even with $15 \%$ deliberatively added sucrose concentration, $\mathrm{C}_{4}$ additive test showed inefficiency to single handedly detect specific $\mathrm{C}_{4}$ plant adulterant, but in combination with other values it could be useful. Using UHPLC-ELSD, the recovery of deliberately added sucrose in adulterated honey is not complete. The slight decrease of sucrose could be naturally explained by sucrose hydrolysis by natural enzymes and the acidic $\mathrm{pH}$ of the natural honey (Se et al., 2019). However, the UHPLC-ELSD method gives better results on specific adulterant sucrose of $\mathrm{C}_{4}$ plant origin than the IRMS method.

\section{ACKNOWLEDGEMENTS}

The Institute of Food Safety, Animal Health, and Environment "BIOR" provided the honey samples. This work was 
supported by the grant "Recognition of monofloral honey of Latvian origin using nuclear magnetic resonance, chromatographic, isotope ratio mass spectrometry and chemometric methods", No. LZP-2020/2-0200.

\section{REFERENCES}

Bateman, A. S., Kelly, S. D., Jickells, T. D. (2005). Nitrogen isotope relationships between crops and fertilizer: Implications for using nitrogen isotope analysis as an indicator of agricultural regime. J. Agric. Food Chem., $\mathbf{5 3}, 5760-5765$

Berriel, V. (2018). Carbon stable-isotope and physicochemical data as a possible tool to differentiate between honey-production environments in Uruguay. Foods, 7, 86

Bocian, A., Buczkowicz, J., Jaromin, M., Hus, K. K., Legath, J. (2019). An effective method of isolating honey proteins. Molecules, 24, 2399.

Chiochini, F., Portarena, S., Ciolfi, M., Brugnoli, E., Lauteri, M. (2016). Isoscapes of carbon and oxygen stable isotope compositions in tracing authenticity and geographical origin of Italian extra-virgin olive oils. Food Chem., 202, 291-301.

Dong, H., Xiao, K., Xian, Y., Wu, Y. (2018). Authenticity determination of honeys with non-extractable proteins by means of elemental analyzer (EA) and liquid chromatography (LC) coupled to isotope ratio mass spectroscopy (IRMS). Food Chem., 240, 717-724.

Geanã, E. I., Ciucure, C. T., Costinel, D., Ionete, R. E. (2020). Evaluation of honey in terms of quality and authenticity based on the general physicochemical pattern, major sugar composition and $\delta 13 \mathrm{C}$ signature. Food Control, 109, 106919
Labsvards, K. D., Rudovica, V., Kluga, R., Rusko, J., Busa, L., Bertins, M., Eglite, I., Naumenko, J., Salajeva, M., Viksna, A. (2022). Determination of floral origin markers of Latvian honey by using IRMS, UHPLC-HRMS, and ${ }^{1}$ H-NMR. Foods, 11, 42.

Magdas, D. A., Guyon, F., Puscas, R., Vigouroux, A., Gaillard, L., Dehelean, A., Feher, I., Cristea, G. (2021). Applications of emerging stable isotopes and elemental markers for geographical and varietal recognition of Romanian and French honeys. Food Chem., 334, 127599.

Schellenberg, A., Chmielus, S., Schlicht, C., Camin, F., Perini, M., Bontempo, L., Heinrich, K., Kelly, S. D., Rossmann, A., Thomas, F., Jamin, E., Horacek, M. (2010). Multielement stable isotope ratios (H, C, N, S) of honey from different European regions. Food Chem., 121, 770-777.

Se, K. W., Wahab, R. A., Syed Yaacob, S. N., Ghoshal, S. K. (2019). Detection techniques for adulterants in honey: Challenges and recent trends. $J$. Food Compost. Anal., 80, 16-32.

Siddiqui, A. J., Musharraf, S. G., Choudhary, M. I., Rahman A. (2017). Application of analytical methods in authentication and adulteration of honey. Food Chem., 217, 687-698.

Vasić, V., Đurðić, S., Tosti, T., Radoičić, A., Lušić, D., MilojkovićOpsenica, D., Tešić, Ž., Trifković, J. (2020). Two aspects of honeydew honey authenticity: Application of advance analytical methods and chemometrics. Food Chem., 305, 1-9.

Wu, L., Du, B., Heyden, Y. V., Chen, L., Zhao, L., Wang, M., Xue, X. (2017). Recent advancements in detecting sugar-based adulterants in honey - a challenge. TrAC, Trends Anal. Chem., 86, 25-38.

Xie, S., Yang, F., Feng, H., Yu, Z., Liu, C., Wei, C., Liang, T. (2020). Organic fertilizer reduced carbon and nitrogen in runoff and buffered soil acidification in tea plantations: Evidence in nutrient contents and isotope fractionations. Sci. Total Environ., 762, 143059.

\section{SAHAROZES PIEDEVU UN GEOGRĀFISKĀS IZCELSMES MARK়IERU NOTEIKŠANA MEDŪ, IZMANTOJOT IZOTOPU ATTIECĪBAS MASSPEKTROMETRIJU UN ULTRA AUGSTI EFEKTĪ̄̄̄̄ S̄S ŠKIDRUMU HROMATOGRĀFIJAS IZTVAIKOŠANAS GAISMAS IZKLIEDES DETEKTORU}

Medu var viegli viltot ar dažādiem lētākiem saldinātājiem, lai iegūtu lielāku peḷnu. Parasti izmanto tādus $\mathrm{C}_{4}$ augu izcelmes saldinātājus kāâ kukurūzas sīrupu, cukurniedru cukuru. Izotopu attiecíbas masspektrometriju (isotope ratio mass spectrometry, IRMS) var izmantot, lai noteiktu medus viltojumu ar $\mathrm{C}_{4}$ augu izcelsmi. Būtiska $\delta^{13} \mathrm{C}$ vērtības starpība starp medu un tā proteīniem sniedz vērtīgu informāciju par medus autentiskumu. Lai novērtētu medus autentiskumu un izcelsmi, tika veikta medus un tā proteīnu IRMS analīze. Papildus tika veikta analīze, izmantojot ultra augsti efektīvās šḳidrumu hromatogrāfijas iztvaikošanas gaismas izkliedes detektoru (UHPLC-ELSD, ultra high performance liquid chromatography - evoparative light scattering detector) viltotam medum. Galveno komponentu analize tika pielietota ar IRMS metodi iegūtajām izotopu attiecībām, lai atrastu diskrimināciju starp grupām vai veiktu novērojumus viltotu paraugu gadījumā. Rezultāti rāda, ka izotopu attiecības vērtības kombinācijā ar galveno komponentu analīzi varētu būt noderīgas dažādu ğeogrāfisku izcelsmju medus noteikšanai un diskriminācijai. Hromatogrāfijas rezultāti uzrāda apzināti pievienotās saharozes atbilstošu pieaugumu, bet sagaidītās vērtības nav pilnībā atgūtas, tomēr aplūkotā hromatogrāfijas metode sniedz labākus rezultātus specifiska $\mathrm{C}_{4}$ augu izcelsmes saharozes medus viltojuma noteikšanai. 